\title{
Effects of Foreign Direct Investment and Trade on Labor Productivity Growth in Vietnam
}

\author{
Hidekatsu Asada \\ Graduate School of Humanities and Social Sciences, Saitama University, 255 Shimo-Okubo, Sakura-Ku, \\ Saitama 338-8570, Japan; asada@mail.saitama-u.ac.jp
}

Received: 6 August 2020; Accepted: 7 September 2020; Published: 9 September 2020

check for updates

\begin{abstract}
Among developing Asian countries that have accelerated their integration with the global economy, Vietnam has achieved remarkable economic development. Vietnam's development strategy prioritizing the promotion of trade and foreign direct investment (FDI) resulted in the rapid transformation of its industrial structure from an agro-based one to one led by the export-oriented manufacturing sector in the past three decades. Given the importance of labor productivity growth on the structural transformation, the study examined the effects of FDI and trade on labor productivity growth in Vietnam in the long run and short run. The study employed the autoregressive distributed lag (ARDL) model of analysis using data from 1990 to 2017. The ARDL model analysis revealed that FDI, capital goods import, and export unanimously contributed to the labor productivity growth in the long run, while the impact in the short run remained ambiguous. The results confirm the theoretical framework augmenting the positive relationship that exists between FDI and trade and labor productivity growth. Vietnam's experience is expected to provide an important lesson to other developing countries.
\end{abstract}

Keywords: labor productivity; foreign direct investment; trade; Vietnam

\section{Introduction}

Developing countries in Asia have accelerated their integration with the global economy since the early 1990s. Globalization's promise has been fulfilled in developing countries in Asia. High productivity employment opportunities have expanded, and structural change has contributed to overall growth (McMillan et al. 2014). An important question is what factors enabled developing countries in Asia to record successful economic development in comparison with other regions such as Latin America and Africa. One of the key answers is that Asian countries make the most of the opportunities provided by globalization. The promotion of trade and investment liberalization has expanded access to advanced capital goods, technology and skills. Opening domestic markets to foreign competitors and foreign direct investment (FDI) inflows improves the productivity of the economy, which results in a more efficient allocation of resources and higher overall output.

Among developing countries in Asia, Vietnam has recorded remarkable economic growth whose average real growth rate was at 6.7\% from 2000 to 2019, making the country one of the fastest growing countries in the region. Vietnam started its development program in the mid-1970s after the end of the US-Vietnam War. The principles of its initial development strategy were a Soviet-style command economy and self-reliance, which only resulted in scarcity, poverty and high inflation. A departure from the Soviet-style command economy and the implementation of a series of gradual transformations towards a market-oriented economy, known as "Doi Moi" (Renovation) started in 1986. Since the implementation of Doi Moi, the government has opened the country to the global economy and diversified its industrial structure, which worked as the catalyst for long-term high growth. As a result of the accelerated integration with the global economy through trade and investment liberalization, 
in 2019 Vietnam's trade (total exports and imports)-to-GDP ratio was $210.4 \%$ (exports at $106.8 \%$ and imports at 103.6\%) (GSO 2019). Vietnam has become a central hub in several global value chains, ranging from garments to mobile phones and computers (OECD 2020). Thanks to its remarkable growth performance, Vietnam joined the group of lower middle-income countries by the World Bank's classification in 2010. In December 2019, the government set the target to achieve high-income country status by 2045 by maintaining the current growth momentum (VnExpress 2019).

The driving forces of the structural transformation include capital accumulation and technology transfer through FDI as well as the reallocation of labor from sectors with lower labor productivity to sectors with higher labor productivity, notably export-oriented manufacturing sector. Exports have contributed to resilient economic growth, which creates a virtuous cycle of increasing exports bringing about increasing imports of advanced intermediate and capital goods.

Vietnam's structural reform efforts have focused on lowering trade and investment barriers and integrating into global value chains, notably through accession to the Association of South-East Asian Nations (ASEAN) and the ASEAN Free Trade Area (AFTA) in 1995, the Asia Pacific Economic Cooperation (APEC) in 1998 and the World Trade Organization (WTO) in 2007. Accession to these trade agreements not only promoted trade and investment liberalization, but also provided an instrument to lock in domestic reform that complemented the liberalization by creating a business-friendly regulatory framework. The domestic reform measures included the introduction of a trade dispute settlement mechanism, creating a level playing field between domestic and foreign firms and protection of intellectual properties (Deprez 2018; Vo et al. 2019; OECD 2020). In particular, the accession to the WTO spurred FDI inflows into Vietnam thanks to these reform measures. Large-scale FDI inflows have created a globally competitive manufacturing base, notably in the semiconductor sector.

However, as discussed in the concept of "middle-income trap" (Gill and Kharas 2007; Kharas and Gill 2020), economic growth led by inputs of production factors such as capital and labor eventually reaches its limit, and the effect of production factor inputs on economic growth gradually diminishes. In addition to a decline of the marginal productivity of capital, factors contributing to this decline include the depletion of surplus labor in terms of labor inputs and a rise in real wages (Lewis 1954). This could lead to the erosion of the competitiveness of the export-oriented and labor-intensive manufacturing sector for lower middle-income countries like Vietnam.

In the context of developing Asian countries, there has been an intense discussion on the factors that enabled them to achieve high growth, including the effects of FDI and trade. Going forward, it is necessary to shift the focus of the analysis and policy recommendations from growth to labor productivity growth. For these countries, to achieve long-term economic growth, labor productivity growth will be a key challenge in terms of upgrading their industrial structure to a high value-added one.

Against this backdrop, this study aims to examine the effects of FDI and trade on the labor productivity growth in Vietnam in the long run and short run. Vietnam provides an interesting example of the rapid transformation of its industrial structure from an agro-based one in the 1980s to one led by the export-oriented manufacturing sector in the past three decades.

The contributions of this paper include: first, to capture the effect of trade on labor productivity growth, the study adopts a novel approach by focusing on the import of capital goods. Imported capital goods are expected to contribute to the improvement of the production process efficiency, and thereby labor productivity. Second, based on the findings, policy recommendations will be discussed to enable Vietnam to benefit from the opportunities that come about as a result of integration with the global economy. This study reveals the positive effects of FDI and trade on Vietnam's labor productivity growth in the long term. This result underpins the importance of integration with the global economy to its reform and development path. Vietnam's experience of its rapid and dynamic industrial transformation will provide an important lesson to other developing countries.

The rest of the paper is structured as follows: Section 2 reviews preceding literature related to FDI and trade and labor productivity growth in general and in Vietnam. Section 3 presents materials and 
methods, followed by results of the analysis in Section 4. Then, Section 5 provides conclusions and policy implications.

\section{Literature Review}

If FDI and trade openness are considered essential parts of integration with the global economy, in what ways could FDI and trade contribute to labor productivity growth? There exists a body of theoretical and empirical research related to this question.

Advocates of the contribution of FDI to labor productivity growth highlight the potential gains from FDI inflows to a country through technology transfer, the introduction of new production processes, management skills, domestic market knowledge, integration with global value chains and access to new markets. These benefits produce positive externalities such as spillover effects of technology and skills (Alfaro et al. 2004; Hale and Long 2006).

Advocates of the positive impact of trade on labor productivity growth also emphasize the importance of access to advanced capital goods and technology. Recent endogenous growth models emphasize the importance of foreign technology and knowledge for long-run growth, and for this purpose, imports are an important channel for them to flow into the domestic economy (Romer 1986; Grossman and Helpman 1991). For example, in a study on Korea's total factor productivity (TFP) from 1980-2003, the effects of imports raised TFP by technological transfers embodied in imports of capital goods from developed countries and by the competitive pressures associated with the imports of consumer goods (Kim et al. 2007).

Regarding the roles of exports, access to advanced production facilities enables firms to increase their capacities of export. Entry to competition in the foreign marketplace provides opportunities to improve production efficiency. Additionally, the promotion of exports also could mitigate the foreign exchange gap, in particular at the early stage of economic development. Greater imports of capital goods and technology can promote further export and labor productivity growth. FDI is an essential vehicle of this process. Eventually, a virtuous cycle of FDI, trade and labor productivity growth can be formulated.

However, despite a number of studies advocating the positive effects of FDI and trade on labor productivity growth as discussed above, numerous studies presented empirical evidence that trade and investment liberalization per se does not necessarily increase output and improve labor productivity. A crucial factor in making the most of the benefits of trade and FDI is the absorptive capacities of the country. The absorptive capacities encompass the economic development strategy of the country, the capability of macroeconomic management, degree of financial development, domestic investment, human capital development, labor market structure and institutional quality (Barro 1996; Blomstrom and Kokko 1998; Baldwin 2003; Thangavelu and Rajaguru 2004; Mallick 2015; Li and Tanna 2019).

Another issue is the timing of materializing benefits of globalization. Malawi and Al Mansi argued that economic globalization brought about by trade and investment liberalization was found to have a positive and a highly significant influence on labor productivity in the long run in Jordan from 1980 to 2010, but this effect was found to be negative in the short run. The contradiction between these two effects of economic globalization may be because globalization may bring about the upgrading of skills through the import or adoption of advanced production technology and innovation, which usually needs a longer time (Malawi and Al Mansi 2014). Narayan and Smyth reached at a similar conclusion in the case of Fiji from 1962 to 2000, finding that a short-run impact of trade liberalization on growth could not be observed in contrast to the positive impact in the long run (Narayan and Smyth 2005).

Given the divergent views on the relationship between FDI and trade and labor productivity growth, it is necessary to explore country-specific analysis of the relationship. From this viewpoint, the experience of Vietnam is worth investigating. The country placed economic opening and integration with the global economy as central to its reform and development path. Vietnam has pursued a 
fast-paced integration strategy aiming for the import of advanced production facilities, technology and skills that contribute to its industrial structure upgrading (OECD 2020).

Regarding the views as to what extent this government's strategy worked, the views are somewhat mixed. Vu examined the contribution of FDI to labor productivity and economic growth of Vietnam in the 1990s by applying time-varying coefficients in an augmented production function and concluded that FDI had significant and positive effects both on labor productivity and economic growth. However, the benefits were not equally distributed among industrial sectors (Vu 2008). Le et al. investigated the effects of FDI and human capital development on Vietnam's labor productivity from 1986 to 2014 by employing the autoregressive distributed lag (ARDL) approach. They found that FDI and human capital development had a significant and positive impact on labor productivity in the long run, while the effects in the short run were ambiguous (Le et al. 2019). Newman et al. surveyed 4000 manufacturing firms in Vietnam from 2009 to 2012 and concluded that direct forward linkages from foreign-invested input suppliers to domestic firms were positively related to productivity. The study also suggested that dominance of foreign firms upstream had a negative impact on the productivity of downstream domestic firms (Newman et al. 2015). Such mixed results suggest the impact of FDI and trade on labor requires further analysis. While much of the preceding literature dealt with the situation up to the mid-2010s, the analysis also needs to be updated to reflect Vietnam's ongoing progress of integration with the global economy. This paper aims to address these issues.

\section{Materials and Methods}

This paper uses the ARDL bounds testing approach developed by Perasan, Shin and Smith to estimate the long-run and the short-run relationships between FDI and trade and labor productivity growth in Vietnam (Pesaran et al. 2001). There are several advantages of the ARDL bounds testing approach. First, it is possible to test the co-integrating relationship among the variables regardless of different orders of integration or mutual co-integration. This is advantageous compared to vector autoregression analysis (VAR) and the vector error correction model (VECM), which need the variables in the model to be the same order of integration. The second advantage is that the inclusion of lagged variables could mitigate endogeneity. Third, it is appropriate to test the long-run relationship among the variables even if the sample size is small.

\subsection{Data Sources}

The study uses annual time series data from 1990 to 2017. The sources of each variable are as follows:

Labor productivity $(L P)$ : $L P$ is annual value-added per worker, calculated by real gross domestic product (GDP) divided by the number of workers. GDP data are at 2017 constant prices. Data are taken from APO Productivity Database 2019 Version 2 produced by the Asia Productivity Organization (APO).

Foreign direct investment (FDI): To ensure consistency with LP, data on gross FDI inflows at the real FDI value are used. Since real FDI value data are not readily available, data are proxied by using the FDI inflows intensity ratio (FDI inflows per GDP) provided by UNCTAD STAT database and real GDP data provided by the APO.

Capital goods import (CIM): To capture the effects of imports on labor productivity, the study focuses on the import of capital goods (UN BEC code 41 and 521) that contribute to improving the efficiency of the production process, and thereby labor productivity. Data on capital goods imports are taken from the RIETI Trade Industry Database 2018 produced by the Research Institute of Economy, Trade and Industry, Government of Japan. They are changed to real value data in the same way as real FDI data as described above. 
Export (EX): Export of goods and services data at 2017 prices are taken from the APO database.

WTO dummy (WTODUM): To reflect the possible impact of a rapid hike of trade and FDI inflows after Vietnam's accession to the WTO in 2007, WTO Dummy is included in the model. The value is set at zero between 1990 and 2006, and one from 2007 to 2017.

Data description is presented in Table 1. $\ln$ is the natural log of each variable.

Table 1. Data description.

\begin{tabular}{ccccc}
\hline & $\ln \boldsymbol{L P}$ & $\boldsymbol{l n F D I}$ & $\operatorname{lnCIM}$ & $\ln \boldsymbol{X}$ \\
\hline Mean & 3.8924 & 18.5675 & 18.3262 & 20.6741 \\
Maximum & 4.5391 & 19.5826 & 20.4949 & 22.3497 \\
Minimum & 3.1839 & 16.8620 & 14.3328 & 18.8050 \\
Std. Dev. & 0.4049 & 0.6989 & 1.9379 & 1.0218 \\
\hline
\end{tabular}

\subsection{Model Specification and Methodology}

The purpose of this study is to examine the effects of FDI and trade on the labor productivity growth of Vietnam. Following the methodology of preceding literature related to this issue (Thangavelu and Rajaguru 2004; Kim et al. 2007; Malawi and Al Mansi 2014; Mallick 2015; Le et al. 2019), the model specification for the econometric analysis is shown in Equation (1):

$$
\ln L P_{t}=\ln \left(\frac{G D P_{t}}{N_{t}}\right)=c_{0}+c_{1} \ln F D I_{t}+c_{2} \ln C I M_{t}+c_{3} \ln E X_{t}+c_{4} \text { WTODUM }+e_{t}
$$

In is the natural log of each variable. $L P$ is labor productivity per worker derived by GDP per number of workers, N. FDI is the gross FDI inflows. CIM is the import of capital goods. EX is the export. WTODUM is the WTO dummy. $e$ is the random error term.

The study uses the ARDL approach to estimate the long-run and short-run effects. For this purpose, the study aims to estimate the co-integration relationship between FDI and trade and labor productivity growth. If co-integration among the variables is confirmed, the model can be specified as a conditional error-model format. This would distinguish between the long-run and the short-run effects of independent variables on labor productivity.

Equation (1) is reformulated, and the ARDL model in this study, assuming the existence of co-integration or a long-run relationship, is specified as follows:

$$
\begin{aligned}
\Delta \ln L P_{t} & =c_{0}+c_{1} E C M_{t-1} \\
& +\sum_{i=1}^{p} \Delta c_{2} \ln L P_{t-1}+\sum_{i=0}^{q} c_{3} \Delta \ln F D I_{t-i}+\sum_{i=0}^{r} c_{4} \Delta \ln C I M_{t-i}+\sum_{i=0}^{s} c_{5} \Delta \ln E X_{t-i} \\
& +c_{6} \text { WTODUM }+e_{t}
\end{aligned}
$$

$\Delta$ is the first difference operator. Lag order of each variable is denoted as $p, q, r$ and $s$, respectively.

$E C M t$, the error correction term that captures the long-run relationship, is defined as:

$$
E C M_{t}=\ln L P_{t}-\left(a_{1} \ln F D I_{t}+a_{2} \ln C I M_{t}+a_{3} \ln E X_{t}\right)
$$

\subsection{Unit Root Test}

As the first step of the ARDL approach, the stationary property of the data is checked. ARDL models require that variables in the models should be integrated of either zero, I (0) or one I (1). The unit root test is conducted in line with the widely-used procedure of the unit root test, the Augmented Dickey-Fuller (ADF) test (Said and Dickey 1984) and the Phillips-Perron (PP) test (Phillips and Perron 1987). The test employed intercepts, and the outputs are presented in Table 2. 
Table 2. Result of unit root test.

\begin{tabular}{ccccc}
\hline & \multicolumn{2}{c}{$\begin{array}{c}\text { ADF Test Statistic } \\
\text { with Intercept }\end{array}$} & \multicolumn{2}{c}{$\begin{array}{c}\text { P-P Test Statistic } \\
\text { with Intercept }\end{array}$} \\
\hline Variables & Level & First Difference & Level & First Difference \\
\hline $\ln L P$ & -0.550 & $-4.288^{* * *}$ & -0.523 & $-4.288^{* * *}$ \\
$\ln F D I$ & $-8.733^{* * *}$ & $-12.756^{* * *}$ & $-6.707^{* * *}$ & $-13.136^{* * *}$ \\
$\ln C I M$ & -2.102 & $-5.492^{* * *}$ & $-4.089^{* *}$ & $-5.510^{* * *}$ \\
$\ln E X$ & -1.404 & $-4.105^{* * *}$ & -1.733 & $-5.287^{* * *}$ \\
\hline \multicolumn{2}{c}{ Note: } & $* * *$ & and & ** indicate significance level at $1 \%$ and $5 \%$, respectively.
\end{tabular}

The result of the unit root test shows at $5 \%$ significance level that $\ln L P$ and $\ln E X$ are integrated of order of one, or I (1). $\ln C I M$ is mixed: I (1) by the ADF test and I (0) by the P-P test. $\ln F D I$ is I (0). Since the variables have a difference of integration of order, the ADRL approach best fits the analysis in this study.

\subsection{Lag Order}

Lag order is initially set at three at maximum under the limited number of observations. An unrestricted vector autoregression model was estimated, and the optimal lag order is selected at three by Akaike Information Criterion (AIC), Hannan-Quinn information criterion (HQ) and other criteria as presented in Table 3.

Table 3. Lag order selection criteria.

\begin{tabular}{cccc}
\hline Lag & AIC & SC & HQ \\
\hline 0 & -6.383244 & -6.184287 & -6.340065 \\
1 & -13.95490 & $-12.96012 *$ & -13.73901 \\
2 & -13.47274 & -11.68213 & -13.08413 \\
3 & -15.52835 * & -12.94191 & $-14.96703 *$ \\
\hline Note: * indicates lag order selected by the criterion.
\end{tabular}

As the next step, the order of distributed lag on the dependent variables is selected by the Akaike Information Criterion (AIC), Schwarz's Bayesian criterion (BIC) and Hannan-Quinn information criterion (HQ) in Table 4. It is concluded that the optimal lag order in Equation (2) is set at $(p, q, r, s)=$ $(1,3,3,3)$.

Table 4. Lag order specification of the ARDL model.

\begin{tabular}{cccc}
\hline Specification & AIC & BIC & HQ \\
\hline$(1,3,3,3)$ & -7.8416 & -7.1102 & -7.6387 \\
$(2,3,3,3)$ & -7.8103 & -7.0302 & -7.5940 \\
$(3,3,3,3)$ & -7.7479 & -6.9191 & -7.5180 \\
$(2,3,3,2)$ & -7.6028 & -6.8715 & -7.3999 \\
$(3,3,3,2)$ & -7.5344 & -6.7544 & -7.3181 \\
\hline
\end{tabular}

\subsection{Bounds Test}

The next step of the ARDL approach is to estimate the coefficients of the long-run relationships and associated error correction model (ECM) using the model. To examine the long-run co-integration relationships among the variables, the bounds tests using the calculated F-statistics from the joint significance of lagged levels of variables is employed to confirm the presence of co-integration. The results of the Wald test (F-Statistic) are presented in Table 5. The results reject the null hypothesis of no co-integration at $1 \%$ level. Therefore, it is concluded that there exists a long-run relationship among the variables in the model, $\ln L P, \ln F D I, \ln C I M$ and $\ln E X$. 
Table 5. Results of co-integration test.

\begin{tabular}{cccc}
\hline \multirow{2}{*}{ F-Bounds Test Statistics } & Significance Level & \multicolumn{2}{c}{ Bound Critical Values } \\
\cline { 3 - 4 } & & I (0) & I (1) \\
\hline \multirow{2}{*}{ F-statistics: 20.598} & $10 \%$ & 2.72 & 3.77 \\
k: 3 & $5 \%$ & 3.23 & 4.35 \\
& $1 \%$ & 4.29 & 5.61 \\
\hline
\end{tabular}

Note: The test is based upon the assumption of unrestricted constant and no trend.

\section{Results of the Analysis}

\subsection{Results of the Analysis: Long-Run Relationship and Short-Term Relationship}

The results of the long-run relation or the error correction term (ECT) are presented in Equation (4) and Table 6:

$$
E C T_{t}=\ln L P_{t}-\left(0.0846 \ln F D I_{t}+0.0315 \ln C I M_{t}+0.3315 \ln E X_{t}\right)
$$

Table 6. Long-run relationship.

\begin{tabular}{cccc}
\hline Variables & Coefficient & t-Statistics & $p$-Value \\
\hline $\ln F D I t$ & $0.0846^{* * *}$ & 6.9349 & 0.0000 \\
$\ln C I M t$ & $0.0315^{* * *}$ & 10.0827 & 0.0000 \\
$\ln E X t$ & $0.3315^{* * *}$ & 46.812 & 0.0000 \\
ECTt & $-0.7565^{* * *}$ & -10.3492 & 0.0000 \\
\hline
\end{tabular}

Note: ${ }^{* * *}$ indicate significance level at $1 \%$ and $5 \%$, respectively.

The coefficient value of the ECT is at -0.7565 and statistically significant at $1 \%$ significance level. This indicates the existence of the long-run relationship between labor productivity $(L P)$ and the other three variables (FDI, CIM and EX).

In contrast to the long-run relationship, the short-run relationship is ambiguous, as presented in Table 7 .

Table 7. Short-run relationship.

\begin{tabular}{cccc}
\hline Variables & Coefficient & t-Statistics & $p$-Value \\
\hline$\Delta \ln F D I$ & $0.0734^{* * *}$ & 13.4552 & 0.0000 \\
$\Delta \ln F D I(-1)$ & $-0.0118^{* * *}$ & -3.6852 & 0.0042 \\
$\Delta \ln F D I(-2)$ & $0.0082^{* *}$ & 2.9332 & 0.0150 \\
$\Delta \ln C I M$ & $0.0115^{* * *}$ & 5.3672 & 0.0003 \\
$\Delta \ln C I M(-1)$ & $-0.0085^{* * *}$ & -3.8405 & 0.0033 \\
$\Delta \ln C I M(-2)$ & $-0.0129^{* * *}$ & -4.9675 & 0.0006 \\
$\Delta \ln E X$ & 0.0030 & 0.1338 & 0.8962 \\
$\Delta \ln E X(-1)$ & 0.0154 & 0.6684 & 0.5190 \\
$\Delta \ln E X(-2)$ & $-0.0992^{* * *}$ & -5.3295 & 0.0003 \\
WTODUM & $-0.0636^{* * *}$ & -10.5438 & 0.0000 \\
Constant & $-3.7867^{* * *}$ & -10.3299 & 0.0000 \\
\hline
\end{tabular}

\subsection{Discussion of the Results}

The results of the ARDL model indicate that FDI, CIM and EX have positive and long-run effects unanimously on labor productivity growth in the period 1990 to 2017 . For example, a $1 \%$ increase in FDI inflows improves labor productivity by $0.085 \%$, and $0.032 \%$ for CIM, and $0.332 \%$ for $E X$, respectively. The results confirm the theoretical framework augmenting the positive relationship that exists between FDI and trade and labor productivity growth that is in line with preceding literature such as (Thangavelu and Rajaguru 2004; Malawi and Al Mansi 2014; Mallick 2015; Newman et al. 2015). 
In contrast to the long-term relationship, the short-term relationship is ambiguous. This result is in line with the findings of preceding literature such as (Narayan and Smyth 2005; Malawi and Al Mansi 2014). This can reflect the process of operation of firms set up by FDI that need multiple years to start their production, in particular if FDI is "greenfield" investment starting the factories from scratch. Another reason is the time required for learning and adopting skills to utilize technology embodied in imported capital goods (Malawi and Al Mansi 2014).

\subsection{Diagnostic Tests}

To check the reliability of the estimation result, a series of diagnostic tests were conducted, and their results are presented in Table 8 . The results of diagnostic tests confirmed the acceptance of the null hypothesis of no autocorrelation, normally distributed residuals and homoskedasticity.

Table 8. Results of diagnostic tests.

\begin{tabular}{cc}
\hline Type of Test & Result \\
\hline Adjusted R-squared & 0.9557 \\
Breusch-Godfrey serial correlation LM test & Obs R-squared 5.0730 (Prob $=0.0791)$ \\
Residual normality test & Jarque-Bera test: $2.5401($ Prob $=0.2808)$ \\
Residual heteroskedasticity test & Obs R-squared 10.1260 (Prob $=0.7529)$ \\
\hline
\end{tabular}

\subsection{Stability Test}

The stability of the estimation is accessed by the cumulative sum (CUSUM) of the recursive residuals test and the CUSUM of squares of the recursive residuals test. The results of these two tests are displayed in Figure 1. Since test statistics of the CUSUM and the CUSUM of squares are within the range of $5 \%$ significance level, it is concluded that the estimated output of the ARDL model is stable.

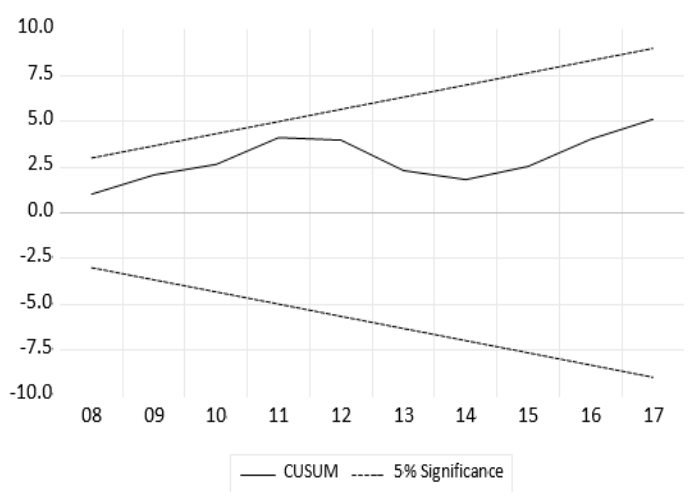

(A) CUSUM test

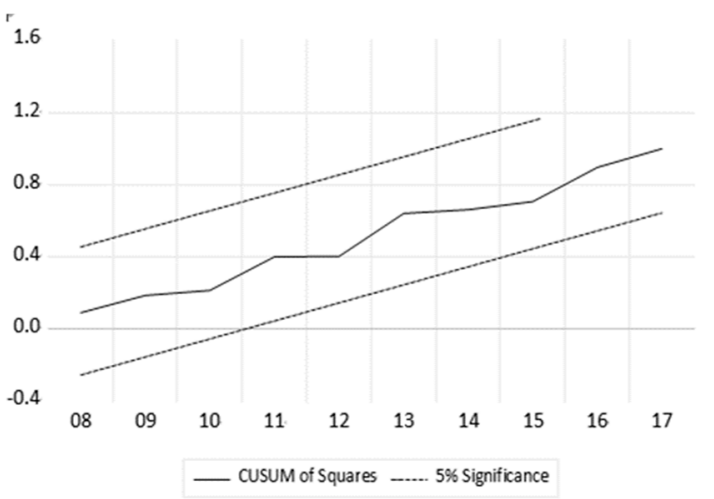

(B) CUSUM-squares test

Figure 1. Results of stability tests.

\section{Conclusions and Policy Implications}

The study examined the effects of FDI and trade on labor productivity growth in Vietnam in the long run and short run while avoiding the risk of the "middle-income trap". The ARDL model exercise revealed that FDI, capital goods imports and exports unanimously contributed to labor productivity growth in the long run, while the impact in the short run remained ambiguous. The results confirm the theoretical framework augmenting the positive relationship that exists between FDI and trade, and labor productivity growth. The results also imply that Vietnam's development strategy prioritizing the promotion of integration with the global economy contributed to its growth and structural transformation into a higher valued-added industrial structure. Vietnam's experience will provide an important lesson to other developing countries that face rising uncertainty brought about by growing scepticism towards globalization. 
However, going forward, favourable conditions that enabled Vietnam to take advantage of integration with the global economy through FDI and trade could diminish, albeit gradually. The decline of rural surplus labor and the consequent rise of real wages reduce the competitiveness of the export-oriented and labor-intensive manufacturing sector, which is Vietnam's current comparative advantage. Moreover, the advent of artificial intelligence and advanced technologies such as robotics and 3-D printing should reduce the importance of cheap labor in the location decision of multinational firms (World Bank 2020). These trends amplify the risk of the slowdown of FDI inflows into Vietnam, and thereby exports.

As existing literature reviewed in Section 2 emphasizes, a country needs a holistic policy framework to enhance absorptive capacity in order to make the most of the opportunities provided by the expansion of FDI and trade. For middle-income countries like Vietnam to achieve long-term economic growth and upgrade their industrial structure to one of a high-income country, ensuring labor productivity growth will be a crucial challenge. The policy framework for boosting labor productivity encompasses the capability of macroeconomic management, domestic financial sector development, human capital development, labor market structure and institutional quality.

Vietnam continues to enhance its strategy to open up the country by trade agreements and simultaneously to use the commitments of the agreements as an instrument to lock in domestic reform to improve its business-friendly regulatory framework (Deprez 2018; World Bank 2020). In this respect, Vietnam has taken further steps to accelerate and enhance the integration with the global economy. A comprehensive set of liberalization and domestic structural reforms were committed to by the ASEAN Economic Community (AEC) in 2015, the Comprehensive and Progressive Trans-Pacific Partnership agreement (CPTPP) in 2019 and the European Union-Vietnam Free Trade Agreement in 2020. In these agreements, liberalization of FDI into services sectors such as telecommunications, transport and finance is included. Expanding the scope of liberalization beyond the manufacturing sector to the services sector is a necessary step to the further improvement of labor productivity, considering the importance of the services sector for the labor productivity growth in Asian emerging countries (Asada 2020).

In the process of upgrading the industrial structure, absorptive capacity becomes more important to translate the expansion of FDI and trade into labor productivity growth. In the process of the implementation of these agreements, the government has planned a series of structural reform measures to boost competitiveness and productivity, such as infrastructure development, business-friendly regulatory reform and realignment of misallocated resources, notably through reform of state-owned enterprises that are a legacy of the command economy era. Moreover, for middle-income countries like Vietnam to promote the upgrading of their industrial structure, governments emphasize policies to improve human capital development and labor skills to ensure positive technology diffusion to domestic firms brought about by FDI inflows (Dinh et al. 2019). For Vietnam's domestic firms, narrowing the technology gap could improve firms' performance. Expanding access to the global economy enables Vietnam's domestic firms to have greater opportunities to absorb technology spillovers and strengthen their production systems (Nguyen et al. 2019). Ensuring the implementation of these reform measures will be key to achieving Vietnam's aspiration to become a member of the high-income country group by 2045 .

Funding: This research received no external funding.

Conflicts of Interest: The author declares no conflict of interest.

\section{References}

Alfaro, Laura, Areendam Chanda, Sebnem Kalemli-Ozcan, and Selin Sayek. 2004. FDI and Economic Growth: The Role of Local Financial Markets. Journal of International Economics 64: 89-112. [CrossRef]

Asada, Hidekatsu. 2020. Impacts of Sectoral Labour Productivity Growth of Emerging Countries in East Asia. Economics Bulletin 40: 906-20. 
Baldwin, Robert. 2003. Openness and Growth: What's the Empirical Relationship? NBER Working Paper. Cambridge: National Bureau of Economic Research.

Barro, Robert. 1996. Determinants of Economic Growth: A Cross-Country Empirical Study. NBER Working Paper. Cambridge: National Bureau of Economic Research.

Blomstrom, Magnus, and Ari Kokko. 1998. Multinational Corporations and Spillovers. Journal of Economic Surveys 12: 247-77. [CrossRef]

Deprez, Sophie. 2018. The Strategic Vision behind Vietnam's International Trade Integration. Journal of Current Southeast Asian Affairs 37: 3-38. [CrossRef]

Dinh, Trang Thi-Huyen, Duc Hong Vo, Anh The Vo, and Thang Cong Nguyen. 2019. Foreign Direct Investment and Economic Growth in the Short Run and Long Run: Empirical Evidence from Developing Countries. Journal of Risk and Financial Management 12: 176. [CrossRef]

Gill, Indermit, and Homi Kharas. 2007. An East Asian Renaissance: Ideas for Economic Growth. Washington, DC: World Bank.

Grossman, Gene M., and Elhanan Helpman. 1991. Trade, Knowledge Spillovers and Growth. European Economic Review 35: 517-26. [CrossRef]

GSO. 2019. Statistical Yearbook of Vietnam 2019. Hanoi: General Statistics Office of Vietnam.

Hale, Galina, and Cheryl Long. 2006. What Determines Technological Spillovers of Foreign Direct Investment: Evidence from China. Economic Growth Center Yale University Discussion Paper. Yale: Economic Growth Center at EliScholar, April.

Kharas, Homi, and Indermit S. Gill. 2020. Growth Strategies to Avoid the Middle-Income Trap. Duke Global Working Paper. Available online: https://ssrn.com/abstract=3526261 (accessed on 7 September 2020).

Kim, Sangho, Hyunjoon Lim, and Donghyun Park. 2007. The Effect of Imports and Exports on Total Factor Productivity in Korea. RIETI Discussion Paper Series 07-E-022: 41; Tokyo: Research Institute of Economy, Trade and Industry.

Le, Nguyen Hong, Luong Vinh Quoc Duy, and Bui Hoang Ngoc. 2019. Effects of Foreign Direct Investment and Human Capital on Labour Productivity: Evidence from Vietnam. The Journal of Asian Finance, Economics and Business 6: 123-30. [CrossRef]

Lewis, William Arthur. 1954. Economic Development with Unlimited Supplies of Labour. Manchester School of Economic and Social Studies 22: 139-91. [CrossRef]

Li, Chengchun, and Sailesh Tanna. 2019. The Impact of Foreign Direct Investment on Productivity: New Evidence for Developing Countries. Economic Modelling 80: 453-66. [CrossRef]

Malawi, Ahmad Ibrahim, and Mattia Al Mansi. 2014. Economic Globalization and Labor Productivity: An application of Autoregressive Distributed Lag (ARDL) Bounds Testing Approach. International Journal of Business and Statistical Analysis 1: 49-55. [CrossRef]

Mallick, Jagannath. 2015. Globalisation, Structural Change and Labour Productivity Growth in BRICS Economy. FIW Working Paper No. 141. Vienna: FIW-Research Centre International Economics.

McMillan, Margaret, Dani Rodrik, and Íñigo Verduzco-Gallo. 2014. Globalization, Structural Change, and Productivity Growth, with an Update on Africa. World Development 63: 11-32. [CrossRef]

Narayan, Paresh, and Russell Smyth. 2005. Trade Liberalization and Economic Growth in Fiji. An Empirical Assessment Using the ARDL Approach. Journal of the Asia Pacific Economy 10: 96-115. [CrossRef]

Newman, Carol, John Rand, Theodore Talbot, and Finn Tarp. 2015. Technology Transfers, Foreign Investment and Productivity Spillovers. European Economic Review 76: 168-87. [CrossRef]

Nguyen, Phuong V., Hien Thi Ngoc Huynh, Hoa Doan Xuan Trieu, and Khoa T. Tran. 2019. Internationalization, Strategic Slack Resources, and Firm Performance: The Case Study of Vietnamese Enterprises. Journal of Risk and Financial Management 12: 144. [CrossRef]

OECD. 2020. Multi-Dimensional Review of Viet Nam: Towards an Integrated, Transparent and Sustainable Economy. OECD Development Pathways. [CrossRef]

Pesaran, M. Hashem, Yongcheol Shin, and Richard J. Smith. 2001. Bounds Testing Approaches to the Analysis of Level Relationships. Journal of Applied Econometrics 16: 289-326. [CrossRef]

Phillips, Peter C. B., and Pierre Perron. 1987. Testing for a Unit Root in Time Series Regression. Yale University Cowles Foundation Discussion Paper. New Haven: Yale University.

Romer, Paul M. 1986. Increasing Returns and Long-Run Growth. The Journal of Political Economy 94: 1002-37. [CrossRef] 
Said, Said E., and David A. Dickey. 1984. Testing for Unit Roots in Autoregressive-Moving Average Models of Unknown Order. Biometrika 71: 599-607. [CrossRef]

Thangavelu, Shandre Mugan, and Gulasekaran Rajaguru. 2004. Is There an Export or Import-Led Productivity Growth in Rapidly Developing Asian Countries? A Multivariate VAR Analysis. Applied Economics 36: $1083-93$. [CrossRef]

VnExpress. 2019. Vietnam Aims at High-Income Status by 2045. VnExpress International. December 30. Available online: https:/e.vnexpress.net/news/business/economy/vietnam-aims-at-high-income-status-by2045-4035010.html (accessed on 1 August 2020).

Vo, Thanh Tri, Duong Anh Nguyen, and Thien Thi Nhan Do. 2019. Economic Consequences of Trade and Investment Liberalisation: The Case of Viet Nam. ERIA Discussion Paper Series. Jakarta: Economic Research Institute for ASEAN and East Asia.

Vu, Tam Bang. 2008. Foreign Direct Investment and Endogenous Growth in Vietnam. Applied Economics 40: 1165-73. [CrossRef]

World Bank. 2020. Vibrant Vietnam: Forging the Foundation of a High-Income Country: Main Report. Washington, DC: World Bank. Available online: http://documents.worldbank.org/curated/en/745271590429811414/MainReport (accessed on 1 August 2020).

(C) 2020 by the author. Licensee MDPI, Basel, Switzerland. This article is an open access article distributed under the terms and conditions of the Creative Commons Attribution (CC BY) license (http://creativecommons.org/licenses/by/4.0/). 